\title{
The Body as a Machine in the Works of Soviet Artists of the 1920s and 30s
}

\begin{abstract}
The article discusses the work of artists active in the 1920s and 1930s in Russia, ${ }^{2}$ the form and content of which links them with the idea of man-machine, which grew in popularity in the age of heightened industrial development and system changes in the $20^{\text {th }}$ century.

The article seeks to present the influence of official guidelines (including cultural and educational policies) and technological change on imagery, and, essentially, to point up the relationship between politics and the form and content of the art.

An overview of artists working notably in Russia focuses on that period of their oeuvre that drew overtly on new solutions in visual arts. These artists are less known in Poland nowadays as they were either artistically enmeshed in Socialist Realism down the line or had a role in sanctioning it.

The paper further dwells on the relationship between the avant-garde, modern art and engaged art at the early stages of forming the new political system. It also discusses problems such as: changes in art prompted by new ways of artistic practice; artist's mutual inspirations; the application of imagery types that had formed earlier (especially when artistic activity had its footing in similar objectives); exemplifications of artists frequently drawing on the artistic traditions of their native country without shunning references to landmark works.
\end{abstract}

\section{Keywords:}

Soviet art, engaged art, Socialist Realism, machine, industrial development, Alexander Deyneka

1 Faculty of Philosophy, Jesuit University Ignatianum in Kraków, Poland. E-MAIL: beata.bigaj@ignatianum.edu.pl ORCID: 0000-0003-1316-375X

2 Since 1922 the Union of Soviet Socialist Republics. 
In Cossacks of the Kuban, a 1949 film by Ivan Pyryev, reapers sing away labouring at harvest. They move agilely and rhythmically, wear colourful and fresh clothes, their figures strapping, healthy and joyful. Women of impeccable looks with fishtail braids tucked under snow-white kerchiefs sing the cheerful tune: "Clean, clean, Yes, load, load, Load, it is time. Oh, our harvest, harvest, Harvest high!”. ${ }^{3}$ Their robust excitement conveys the full-blown socialist optimism of the late 1940s USSR, ${ }^{4}$ when propaganda absurdities sanctioned by political programmes gobbled up the creative energy. But not so long before, in the early 1920s, when a new order was only being built in the Soviet Russia, the artists' enthusiasm was genuine at grassroots. One of those who succumbed to the idea of building the new order based on new art was Alexander Deyneka ${ }^{5}$ - "person incredibly gifted and, most importantly, sensitive to the spirit of the times, he was driven by an ambition to create a new, Soviet style of art [...] based on the cult of health, sport, labour and what followed from it - a new life, new family, new way of life" (Yeerev, after: Lazarev, 2011). "We the young began to work on virgin soil” - wrote Deyneka "We have fallen in love with our days and our art. This is our life, and the great powerful constructive beginning of our labouring people” $(1936,1918)$.

Alexander Deyneka, a major Soviet visual artist born in 1899 in Kursk, confronted various external factors in his creative work, which got reflected in his oeuvre. "In terms of style, Deyneka experienced at least three transformations: in the 1920s, in the 1930s and in the 1940s-1960s” (Lazarev, 2011). In the 1920s, his visual language proved he kept abreast with the latest movements: Cubism, Futurism and also Suprematism. ${ }^{6}$ Like many artist in the field where the revolution and war gave birth to a new era, he expected the new reality to hold a place for a new art based on most modern visual solutions. Orlando Figes (2009) says that in post-revolutionary Russia there was no censorship of art, which made it an area of relative freedom, hence, paradoxically, a police state saw an artistic eruption. Soon after the revolution, the helms of the previously existing and newly emerging art institutions were taken by avant-garde artists such as Vladimir Tatlin, Wassily Kandinsky, Kazimir

\footnotetext{
Urozhainaia, music by I. Dunaevsky, lyrics by M. Volpyn, M. Isakovsky.

See: Kaczorowski, 2008, pp. 546-551; Możejko, 2001.

5 In other transcriptions we can find him as a: Alexandr/Aleksandr/Alexander Deineka/ Deyneka.

6 "The hypothesis that Alexander Deineka's body of work is a Bildungsroman of this process requires that Socialist Realism be understood as the continuation of Futurism and Suprematism, albeit by different means. As Ekaterina Degot has pointed out, "without Malevich, Socialist Realism is not possible, which allows us to see the futurist Malevich as a kind of ancestor of Deyneka” (Fontán del Junco, after: Witschey \& Wolf, 2011, p. 53).
} 
Malevich, ${ }^{7}$ and the Higher Art and Technical Studios known as Vkhutemas were set up in Moscow with a course programme designed by Kandinsky. Among the trainers where Tatlin and Malewicz (Porębski, 1988, p. 348), and in 1927 it got renamed Vkhutein, or the Higher Art and Technical Institute. Initially condoned, the revolutionary avant-garde trends turned around due to circumstances both artistic and political-social, resulting "in a gradual revival of realism, championed by the Peredvizhniki (lit. the Wanderers or the Itinerants), who resumed their exhibitory activity” (Porębski, 1988, p. 351). ${ }^{8}$ The majority of artistic movements seeking to brings art close to the masses (such as the Russian Artists' Union or the Association of Artists of Revolutionary Russia - AKhRR) were gradually building a programme of Socialist Realism, yet there were among them some who advocated more modern styles, like "[...] the graduates of the Moscow Vkhutemas, who set up Obshchestvo Stankovistov (the Society of Easel Artists or OST) in 1925: Alexander A. Deyneka [...] and Yuri I. Pimenov” (Porębski, 1988, p. 352).

The hesitation between the utopian theory of art for the masses (which developed in the late 1920s and was entrenched in tradition) and a desire to apply modern visual techniques comes through in the difference between the sketch and final version of Textile Workers, a 1927 canvas by Deyneka. The original featured four female workers (in the end, Deyneka removed one of them). The worker in the foreground looks very modern: a young girl sweeping her hair back with a sensual gesture. Two women further in the back have more traditional figures: their heads are covered with kerchiefs, one is wearing an outfit typical of a woman working the field. In the final, oil version of the painting, all the figures are given futuristic appearance: women in clothes standardised in their whiteness, slim, sporty, ${ }^{9}$ reminiscent of astronauts without uniforms. The looms outlined with circles and rectangles look like dashboards of a machine of the future. Only the cows led along the street outside the window show we are on the Soviet, peasant-worker soil. The robotised world of the textile mill is redolent of Futurist paintings but the message reached even further: it is not only about motion, dynamics and the modernity of the human figure but about the automation of the new man working like a machine and as efficiently as a machine.

7 The Moscow Collegium on the Arts, a section of Narkompros (The People's Commissariat for Education).

8 The Peredvizhniki - the Society for Travelling Art Exhibitions, a Russian art group founded in Sankt Petersburg in 1870.

9 Sometime later, following certain modifications to his style, Deyneka commented on this painting: "I do not understand the use of the industrial landscape, since a deformed human figure turned out weak and enslaved in it” (Stremmel, 2008, p. 42). 
The idea of man-machine emerged at the time as an instrument to improve the material status of the hungry Russia. From the West came concepts that the government fondly accepted: cheap, rational and mechanised production. Both Lenin and Trotsky appreciated Frederick W. Taylor's work management theories based on studies in operational efficiency, as well as Henry Ford's manufacturing innovations, where the manufacturing process was divided into sections in which each worker performed only one specific element of the process (Figes, 2009). In keeping with his Western colleagues' guidelines, Alexei Gastev, head of the Central Institute of Labour, formulated 16 Rules for Every Occupation, widely trusted for their care for work ergonomics (e.g., workstation should be set up so that one can work comfortably and not get unnecessarily tired by assuming an inappropriate posture). At the same time they prescribed work at a steady pace, free of any redundant emotions or ambitions: "It is a very bad habit to show self-satisfaction when a task is successfully completed. Here, it is necessary to hold out, so to speak, to get used to success, quell your satisfaction and internalise it or we will poison our will and the work will turn against us” (Gastev, 1973). ${ }^{10}$ In post-revolutionary Russia, Gastev was provided with adequate conditions for experiments and studies. What is more, he had the power to turn his findings into prescriptive regulations. In line with his guidelines, factories saw "[...] Hundreds of identically dressed trainees would be marched in columns to their benches, and orders would be given out by buzzes from machines. The workers were trained to hammer correctly by holding a hammer attached to and moved by a hammering machine” (Figes, 2009, p. 768). Ultimately, a nameless man identifiable only by a code was to function "unburdened" by individual thinking, obedient to machines and useful for the collective. But for the idea of a human robot to become the manufacturing reality, the future worker had to be formed first, taught how to live by the rules, and made efficient so as to withstand tedious and hard labour. Educational regulations that stressed training in the spirit of physical culture proved helpful. In a paper given in 1928 at a conference of social studies lecturers, Anatoly Lunacharsky, one of the founders of the educational system in the USSR, ${ }^{11}$ postulated: "We cannot think of bringing up a generation presenting high work capabilities if they are of feeble muscles, underdeveloped backbones and faint hearts", and the new man should be "[...] built with faculties that add up to an integrated organism, the same

10 More on the psychology of labour and movements in mechanical operations at production - see, e.g., Nowacki, 1962, pp. 189-193.

11 Lunacharsky also repeatedly outlined the tasks of art in the new system - see: Lunacharsky (1969) [The Tasks of Social Democratic Artistic Works, 1907]. 
way we construct a machine, taking care no part comes in the way of another, for optimum efficiency of the entire machine” (1961, pp. 184, 181).

By and by, the concepts of the human robot (or more broadly: man-machine) came under the fire of criticism, ${ }^{12}$ yet they coincided in visual arts with a fascination with industry, observed already back in the age of technological change in the $19^{\text {th }}$ century. In the time of political and social change at the outset of the $20^{\text {th }}$ century, that interest had a formative effect on the theme of a strong, musclebound man delineated in strongly angular forms and evocative of industrial design. The art of many different countries glorified the man-machine, notably murals by Diego Rivera that hardly make any differentiation between machine parts and the human inscribed in them. Rivera's fresco at the Detroit Institute of Arts (sponsored by Henry Ford's son, Edsel B. Ford, the then President of Ford Motor Company), takes up four walls of the Garden Court, and appears to be the artist's attempt to challenge the form and content of the Sistine Chapel. Here, however, the accentuation of the divine power is replaced by a celebration of a machine that towers over the workers feeding it. On the northern wall, men being forced to operate in a machine-like rhythm seem to be an inseparable element of the system, a model for which was a Ford manufacturing plant. The shape and colour of the human in the machine's embrace make him blend in with it, and his figure is arranged so as to uncover the heart of the project located centrally on the fresco: a blast furnace (see: Kettenmann, 2003, pp. 49-51). Examples of similar solutions are found in the painting art of the Soviet Union. Two years before Rivera completed his work, in 1931, Alexander Samokhvalov executed Repairing a Locomotive, a canvas a lot smaller than the mural by the Mexican artist but likewise integrating man into the clockwork of the machine. Centrally positioned in the painting, two men repairing a machine stand on the steps of a locomotive, their bodies arranged into a letter $\mathrm{L}$ turned upside down. Another three workers are busy with other operations: the one tightening the screws on the wheel mechanism may bring up associations with Leonardo's Vitruvian Man. The machine and man are one here: they share their shape, chiaroscuro treatment and even colour.

12 One of the first writers to describe the absurdities of the idea of man-machine was Yevgeny Zamyatin, the author of We (1920). Zamyatin wrote: “The digits marched, four abreast, enthusiastically stomping to the beat - hundreds, thousands of digits, in their bluish unifs, with gold badges on their chests, bearing the state-issued numbers of each male and female. And I - we, the four of us - were one of the countless waves in this majestic stream” (Zamyatin, 2003, p. 4). In his novel, Zamyatin emphasised interest in Taylor's theories: "The beauty of a machine is in its rhythm, steadfast and precise, like a pendulum. But, brought up from early childhood on the Taylor system, have you not become as precise as pendulums?” (2003, p. 148). 
These two "post-breakthrough" painters active in different countries doubtless knew about each other and knew each other's art. Consciously or not, they shared certain patterns; ideas and inspirations migrated. What stems from what? The image of a man entangled in an assembly of screws and pistons is derived from a theory of the work collective, fascination with industry, political propaganda as well as interest in Cubism and Futurism, which required that shapes be inscribed in geometric forms and motion be segmented. Modern art influences are apparent in pieces by Samokhvalov: his canvases presenting female workers constructing the subway ${ }^{13}$ are clearly derived from Cubism. In one of them, a fashionably clad drill operator ${ }^{14}$ with a shoulder strap of her overalls sensually slinging down her arm, is contained within excavated walls, their form leaning towards geometric abstraction. The background and the woman's body are complementary: one seems to be part of the other, which suggests the artist was familiar with the analytical phase of Cubism, where objects melted into space. The worker's strong hands no doubt come from her experience of hard work but that might as well be a deformity intrinsic in synthetic cubist painting. Did similar impacts produce the articulated body parts seemingly pivoting on screw joints in Deyneka's and Pimenov's paintings? This is one of them: Deyneka's Football (1924) showing four players with superbly rendered dynamics of their bodies. The joints of the limbs are conspicuous: the knees, shoulders, elbows and wrists seem to be underlined by the curves, an impression enhanced by colour differences and spherical drops of light. In Pimenov's Footballers (1928), enhanced by chiaroscuro, the circles of the shoulders, buttocks, knees, calves unerringly accentuate motion just as they assert the boys as young, healthy, able-bodied and brawny new gods of an activity that lives up to the expectations and needs of the era.

Things are in total interplay, and in terms of content, what emerges before us is the invincible man of new society: strong, physically and mentally fit, able to play and to strive for a new quality of life. To represent him, the artist applies the language of the new art. He integrates new theories and new forms, incorporating into all that the latest scientific findings. Interest in the manufacturing process and efficiency triggered the development of studies of movements of the human body. Down the line they would lay the groundwork for ergonomics but for the time being the objective was to determine what is best for industry and how to translate natural human kinematics to the motions of a machine operator. Films were made that studied human movements projecting the work of muscles and points of bending

13 A. Samokhvalov: Metro Construction Worker with a Concrete Mixer, 1937; Metro Construction Worker with a Spade, 1934 (see: Zinger, 1982).

14 A. Samokhvalov, Metro Construction Worker (1937). 
with light-doted curves to highlight the knees, calves and shoulders. In the USSR, Nikolai Bernstein, a Russian neurophysiologist, used the cyclographic technique to trace human movements (see: Sirotkina \& Biryukova, 2015). His interest in phases of motion originated at the Moscow Central Institute of Labour, where he studied metal cutting operations and, from 1926 on, human walking. There is a film that overviews the scientist's achievements, ${ }^{15}$ in which athletes exercising in one of the scenes wear special bands on their heads and small lights attached at points most critical for the execution of movements. Shot at low illumination levels, the small lights draw the trajectory of their motions. With the frame rate of 200 frames per minute the maker was able to set apart every intermittent phase which he then analysed thoroughly. The outcomes of his experiments contributed to the knowledge of human movement, were helpful in optimizing productivity and supported Russian successes in sports. Was it a coincidence then that painters would likewise highlight motions with luminous curves in their works?

Sport and fitness were popular subjects in the art of the age. After all, in order to build the new order man had to be strong. A 2015 exhibition at Moscow's Manege, entitled Romantic Realism. Soviet Painting 1925-1945, ${ }^{16}$ presented Deyneka's and Pimenov's paintings in the New Man New Body section. They featured supple and young bodies of athletes or boys and girls at leisure. Veiled only with T-shirts and shorts, the figures' firm, hale carnality was fully justified: a body fit enough to meet the stamina requirements needs to be fought for. ${ }^{17}$ But there was more to that. According to Georges Vigarello (2014, p. 332), when sport won widespread appreciation, it grew to be increasingly 'in demand' among opinion leaders, and, at the same time, an attractive medium for various messages and propagandas: the more attractive the wider its appeal because it played on deep community values. And these would be even more engaged in the totalitarian systems of the 1930s. In the Soviet Union, sport came together with a need to show the face of the new man because "[...] it was especially important to show the active, creative nature of Soviet men and women” (Novouspensky, 1979, p. 12). Artists gained an opportunity to explore one of the leading themes in art and show the beauty of the human body. Some like Deyneka made body and sport one of the most frequent subject in their visual projects. Deyneka wrote: "Sport has one wonderful feature: it can safely fit into a very wide variety of artistic framework. This subject is inexhaustible because it is democratic and popular. Sport accommodates within

15 Nauchnyie osnovy fizichesko i kultury [The Scientific Foundations of Physical Culture], cinematography by N. Vikhirev, c. 1948.

16 Included paintings by I. Brodsky, A. Laktionov, K. Petrov-Vodkin, A. Labas.

17 See: A. Deyneka, Goalkeeper (1934); P. Kuznetsov, Push Ball (1931). 


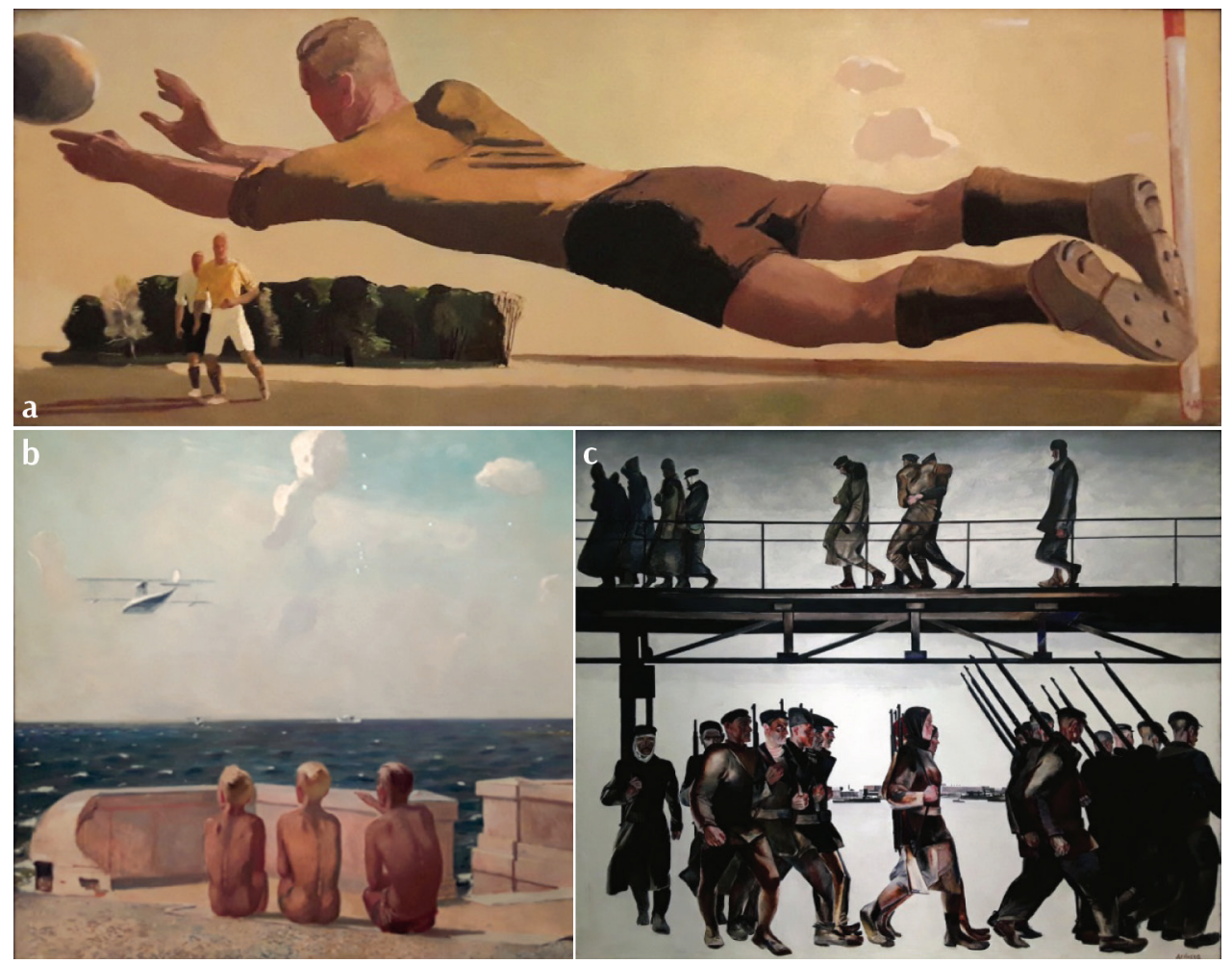

Illustration 1. a) A. Deyneka, Goalkeeper (1934) (il. Voronovich, 2017, pp. 24-25); b) A. Deyneka, Future pilots (1937) (il. Chegodaev, 1983); c) A. Deyneka, The Defence of Petrograd (1928) (il. Voronovich, 2017, pp. 10-11)

Source: author's private notes from visits at Tretyakov Gallery in Moscow

itself shades of feeling - it is lyrical, it is positive and full of optimism. It draws on heroic origins". ${ }^{18}$ The men in paintings by Deyneka or Samokhvalov (who used images of sports equally often ${ }^{19}$ ) have figures that clearly hark back to classical Greek heroes, ${ }^{20}$ whether they are doing sports or physical labour. Studies of the body, conscious of physiological constraints such as range of motion or muscle tensions, reflected the current scientific knowledge, and the saliency given to its potential in sport or work scenes built up the myth of a man finding fulfilment in

18 Quoted after The World of Soviet Sport in 20 $0^{\text {th }}$ Century Russian Art (2013).

19 For example, A. Samokhvalov: Girl in a Footballer's Shirt (1932), Girl with a Shot (1933), On the Stadium (1931), On the Stadium (1935).

20 For example, A. Deyneka, Boys Running Out of the Water (1935), Bathing. After the Fight (1937-42). 
both these roles. Both themes, sports and men at work, give an additional opportunity to stoke the viewer's senses - perfect examples are Samokhvalov's pieces like After Swimming (1935), or Metro Construction Worker with a Drill (1937). It seems there was wide spread acceptance for this kind of interpretation of social and work topics at the time, as it would bring the heroes from the heights of Mount Olympus down to the contemporary flatlands, and talk about matters that were close to everyone. And with regard to women, sensuality was an element of their identity as contemporary citizens: potent, intelligent and aware of their assets.

Some interesting elements in those paintings are the period attributes and instruments used for specific activities: footballs, cross-country skis, racing cars. ${ }^{21}$ A car driver is not only a user of the machine: he relies on it the same way he does on the tools he uses for industrial work. A fit man's power of muscles can face up to even the biggest "monsters" of modern industry. The musclebound males pulling a machine (train cars?) in Pimenov's Give to Heavy Industry (1927) appear ever so different from the workers hauling a vessel in Repin's Burlaks on the Volga (1870-73). The latter were tired, malnourished and dressed in rags while the former are half-naked semi-gods of the new age, with upper bodies glowing as if greased with oil, easily cope with the steel beasts. Sturdy, perfect, almost inhuman and mechanical, these bodies were not, however, an expression of any anti-humanist approach. In Boris Groys’s word (2011, p. 78), "Here it is important to understand that the mechanization of the human body was not the result of an 'anti-humanist' attitude on the part of the avant-garde, as it was often described by the avant-garde critics. Rather, it was an answer to the mortality of the human body under the conditions of the radically modern, e.g. radically materialistic, worldview that rejected any escape from corporeal finitude into the imaginary kingdom of immateriality, spirituality and transcendence. [...] To become immortal the 'natural' human body had to become artificial, machine-like".

It is interesting to look at these images of the human body in the context of Soviet artists drawing on the history of art and landmark Russian and non-Russian works. For example, Deyneka's The Defence of Petrograd (1928) makes an express reference to Hodler's Jena Students Depart for the War of Liberation 1813 (1908-09); his images exploring the naked body ${ }^{22}$ are reminiscent of a variety of masters of nudes (among them, Peter Paul Rubens, Pierre-Auguste Renoir or, most

21 For example, K. Vialov, Motorcycle Riders (1923-25), P. Williams, Racing Cars (1930).

22 For example, A. Deyneka, Bathing Girls (1933), Boys Running Out of the Water (1935), Bathing. After the Fight (1937-42). 
notably, Paul Cézanne ${ }^{23}$ ), and the pieces featuring down falling figures ${ }^{24}$ seem to share a lot with works by Mark Chagall. ${ }^{25}$ Likewise, references to works by other artists can be found in the art of Pimenov or Pyotr (Peter) Konchalovsky (the ornamentation in his Portrait of Vsevolod Emilyevich Meyerhold of 1937 gives it the traits of Henri Matisse's ornamentation).

Derived from the spirit of the avant-garde, the geometrised works by Soviet artists of the 1920s and 1930s exude modernity, and their fresh visual language emphasises the break through character of the period. However, it soon turned out that this modernity had an impediment that would provoke the political makers of the new order to curtail artists' rebellious ambitions. Lyrical images by $19^{\text {th }}$-century artists accentuated the sitter's individualised looks, and the difference between the facial features and expression played a considerable role. Here, in line with modernity's movements, where cubic representations lead to schematisation, the figures are stripped of their individual features and expression. While this reflects the idea of collectivization, ${ }^{26}$ the barge-hauling burlaks and their misery are likely to strike a chord with us much more than Deyneka's figures dating from the 1920s and 1930s, whom we may, indeed, admire as unattainable models of manliness in the crowd but - who are they as individuals? Are we able to identify with them? Are we able to simply like them as people? Is this not, perhaps, one of the reasons why the swaggering, husky and characterful tones were on the wane in the painting of leading Russian artists in the late 1930s and early 1940s? This might as well have been a symptom of changing vogues in painting style and definitely an effect of Socialist Realism and its solidifying theories, ${ }^{27}$ nevertheless the austerity or, one might say, specific ugliness of canvases by modern Soviet artists disappeared towards the mid- $20^{\text {th }}$ century. Later, they veered towards more realistic or impressionistic style, and their works would turn more "orderly".

Today, negative criticism of the Soviet system often times overshadows interpretations of the country's art of the 1920s and 1930s. The utopian theories of manmachine turned out hardly humanitarian in practice, although they revolutionised the management of manufacturing processes with enduring effect. Looking at the paintings dating from the first half of the $20^{\text {th }}$ century in Russia we need to

23 See various bather paintings by Renoir or Cézanne.

24 For example, A. Deyneka, The Defence of Sevastopol (1942), Downing an Ace (1943).

25 For example, M. Chagall, Introduction to the Jewish Theatre (1920), The Fall of Icarus (1975).

26 For the idea of collectivisation in poster art see: Leinwand, 1998, p. 207.

27 And, consequently, of USSR government guidelines and orders. 
remember that whatever the epoch, masterpieces of art are contextually set in their time: the period's history, politics and outlook, while any evaluation of the artistic merit of visual works must take into account the components indispensable for and characteristic of their form: composition, proportions, sign structure, drawing, light, etc. ${ }^{28}$ Referring to the content of Deyneka's works, Andrei Chegodaev (1983) wrote: "He was able to express these ideas not formally or superficially, not through his subject matter or a hackneyed set of situations, poses and gestures, but by means of a strict, pellucid, purposeful yet highly subtle interplay of all elements of artistic form - composition, colour scheme, space, motion and rhythm”.

\section{References}

Chegodaev, A. (1983). Alexander Deineka. Leningrad: Aurora Art Publishers.

Chesnokov, V. (1964). Gosudarstvennaya Tretyakovskaya galereya. Moscow: Sovetskii Khudozhnik.

Diego Rivera's Detroit Industry Murals (n.d.). Bridgeman Images. Retrieved from: http:// www.bridgemanimages.com/en-US/diego-rivera-s-detroit-industry-murals [access date: 6.06.2018].

Deineka, A. (1918). The Art of Our Days (E. Wolf, Trans.). In: E. Witschey, E. Wolf, \& Department of Exhibitions (Eds.) (2011), Aleksandr Deineka (1899-1969): An Avant-Garde for the Proletariat (p. 393). Madrid: Fundación Juan March.

Deyneka, A. (1936). Autobiographical Sketch (E. Wolf, Trans.). In: E. Witschey, E. Wolf, \& Department of Exhibitions (Eds.) (2011), Aleksandr Deineka (1899-1969): An AvantGarde for the Proletariat (p. 394). Madrid: Fundación Juan March.

Figes, O. (2009). Tragedia narodu: Rewolucja rosyjska 1891-1924. Wrocław: Wydawnictwo Dolnośląskie.

Fontán del Junco, M. (2011). Aleksandr Deineka: The Mimesis of a Utopia (1913-53). In: E. Witschey, E. Wolf, \& Department of Exhibitions (Eds.) (2011), Aleksandr Deineka (1899-1969): An Avant-Garde for the Proletariat (pp. 30-55), Madrid: Fundación Juan March.

Gastev, A. (1973 [1922]). Kak nado rabotat' [How to Work]. Moscow: Economica. Retrieved from:https://ruslit.traumlibrary.net/book/gastev-kak-nado-rabotat/gastev-kak-nado-rabotat.html.

Gibka, S. (Ed.) (1994). Leksykon malarstwa od A do Z, od poczq̨tków do współczesności. Warszawa: MUZA S.A.

Groys, B., Aleksandr Deineka: The Eternal Return of the Athletic Body. In: E. Witschey, E. Wolf \& Department of Exhibitions (Eds.) (2011), Aleksandr Deineka (1899-1969): an avant-garde for the proletariat, (p. 78), Madrid: Fundación Juan March.

28 Referring to a specific propaganda concept, this paper focuses on artistic issues without evaluating the effect of the propaganda in visual arts on the history of Russia. For a wider discussion of the influence of agitprop in art on society in Russia in the period covered here, see for example: Leinwand, 1998. 
Goscilo, H. (2017). Deineka’s Heavenly Bodies: Space, Sports, and the Sacred. In: V. Strukov, \& H. Goscilo (Eds.), Russian Aviation, Space Flight and Visual Culture (pp. 53-88). London-New York: Routledge.

Kaczorowski, B. (Ed.) (2008). Epoki i kierunki w kulturze. Warszawa: PWN.

Karpenko, M., Kirillina, Y., Pribulskaya, G., \& Vatenina, N. (Eds.) (1985). Ilya Repin. Painting. Graphic Arts. 1844-1930. Leningrad: Aurora.

Kettenmann, A. (2003). Diego Rivera 1886-1957: A Revolutionary Spirit in Modern Art. Köln: Taschen.

Lazarev, M. (2011). Alexander Deineka: The Artist Through Time. The Tretyakov Gallery Magazine, 1. Retrieved from: https://www.tretyakovgallerymagazine.com/articles/12011-30/alexander-deineka-artist-through-time [access date: 6.06.2018].

Leinwand, A.J. (1998). Sztuka w służbie utopii: o funkcjach politycznych i propagandowych sztuk plastycznych w Rosji Radzieckiej lat 1917-1922. Warszawa: Instytut Historii PAN, Mazowiecka Wyższa Szkoła Humanistyczno-Pedagogiczna w Łowiczu.

Liperovskaya, G.N. (Ed.) (2004). Russia’s Masterpieces. Golden Map of Russian Art. The State Tretyakov Gallery, Moskwa: Scanrus.

Lunacharsky, A. (1962 [1928]). Zadania wychowawcze szkoły radzieckiej. In: A. Lunacharsky (M. Szulkin ed.), O oświacie ludowej (pp. 176-196). Warszawa: Iskry.

Lunacharsky, A. (1969 [1907]). Zadania socjaldemokratycznej twórczości artystycznej. In: A. Lunacharsky (S. Halbersztadt ed.), Pisma wybrane. Vol. 3 (pp. 813-836). Warszawa: Książka i Wiedza.

Możejko, E. (2001). Realizm socjalistyczny. Teoria. Rozwój. Upadek. Krakow: Universitas.

Mumford, L. (2012 [1967]). Mit maszyny. Technika a rozwój człowieka. Vol. 1. Warszawa: PWN.

Nowacki, T. (1962). Zarys psychologii. Warszawa: PWSZ.

Novouspensky, N.N. (1979). The Russian Museum Painting. Leningrad: Aurora Art Publishers.

Porębski, M. (1988). Dzieje sztuki w zarysie. Vol 3: Wiek XIX i XX. Warszawa: Arkady.

Pyryev, I. (1949). Kubanskije Kazaki [Cossacks of the Kuban]. Moscow: Mosfilm.

Sirotkina, I., \& Biryukova, E. (2015). Futurism in Physiology: Nikolai Bernstein, Anticipation, and Kinaesthetic Imagination. In: M. Nadin (Ed.), Anticipation: Learning from the Past: The Russian/Soviet Contributions to the Science of Anticipation (pp. 269-285). Berlin: Springer.

Stremmel, K. (2008). Realizm. Köln: Taschen/TMC Art.

Urozhainaia. Music by I. Dunaevsky, Lyrics by M. Volpyn, M. Isakovsky. Retrieved from: http://www.kino-teatr.ru/kino/movie/sov/3351/song/ [access date: 6.06.2018].

Voronovich, E. (2017). Aleksandr Deineka. Moscow: State Tretyakov Gallery.

Vigarello, G. (2014 [2006]). Stadiony. Widowisko sportowe - od trybun do ekranów. In: J.J. Courtine (Ed.), Historia ciała. Vol. 3: Różne spojrzenia. Wiek XX (pp. 319-345). Gdańsk: Słowo/obraz/terytoria.

Vikhirev, N. (c. 1948). Nauchnyie osnovy fizichesko i kultury [The Scientific Foundations of Physical Culture].

The World of Soviet Sport in 20 th Century Russian Art (2013). Huffpost. Retrieved from: https:// www.huffingtonpost.com/2013/12/30/soviet-art-soviet-sport_n_4493912.html [access date: 6.06.2018]. 
Zamyatin, Y. (2003 [1920]). We. Linda S. Farne Trans., ENC Press.

Zdes' slishkom Stalinym pakhnet (2015). Trud. Retrieved from: http://www.trud.ru/article/1511-2015/1331018_zdes_slishkom_stalinym_paxnet.html [access date: 6.06.2018].

Zinger, L. (1982). Aleksandr Samokhvalov. Moscow: Sovetsky Khudozhnik. 